韦柳端, 朱济友, 李夏榕, 孙广鹏, 张新娜, 徐程扬. 根系功能性状对干瘦立地适应的种间差异一一北京石质山地主要观赏树种为例. 生态学报, 2021,41(23):9492-9501.

Wei L D, Zhu J Y, Li X R, Sun G P, Zhang X N, Xu C Y.Interspecific trait variation in the adaptation of root functional traits to dry-barren sites: A case study of the main ornamental tree species in stony mountainous region of Beijing.Acta Ecologica Sinica,2021,41(23) : 9492-9501.

\title{
根系功能性状对干癒立地适应的种间差异
}

——北京石质山地主要观赏树种为例

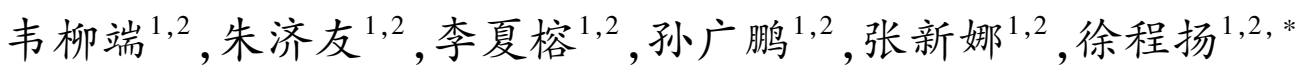 \\ 1 北京林业大学城市林业研究中心, 北京 100083 \\ 2 干旱半干旱地区森林培育及生态系统研究国家林草局重点实验室, 北京 100083
}

摘要:分析干痒立地中不同树种根功能性状的变化及差异,研究不同树种对干痊环境的适应对策。试验材料为林龄、林分密度 相对一致的石质山区主要观赏树种 (黄栌、山桃、栓皮栋), 采用挖掘法获取树木细根,测定细根形态参数。根据田间持水量和 石砾含量分别设置 4 个干痒梯度 (轻度、中度、重度、极度), 对比分析北京干癐地 3 种树种根功能性状, 探讨干痊立地中不同树 种根系形态的差异及其对特殊生境的适应。结果表明:干旱、㾑薄均对树木的根功能性状产生影响,但对不同性状以及不同树 种的影响程度具有差异,其中对山桃根系的影响最大; 3 种树种根功能性状在不同干痊等级下存在显著变化,同一性状的变化 因树种不同而异。从轻度到极度干旱, 3 种树种的 RL 均逐渐减小,但是黄栌变化不显著; 黄栌、栓皮栎 RTD 随干痊的加剧而减 小, 而山桃随干痊的加剧而增加; 黄栌和山桃 SRL 随干旱、痊薄的加剧, 表现出一致的规律, 即从轻度到极度, 其 SRL 随即楲小, 而栓皮栋 SRL 随干旱、痊薄的加剧而增大; 随干痊的加剧, 黄栌 SRA 显著减小, 山桃、栓皮栋 SRA 随干㾑的加剧而增大。树木对 干痊环境的变化都有一定的响应能力及适应对策,能够通过自身的形态变化来适应不断变化的环境,但不同物种对干瘦环境变化 的适应途径不同,通过权衡碳分配、碳消耗采取了相应的生态适应策略,不同树种间存在明显差异。本研究 3 种树种中, 黄栌在干 痊环境下根系性状变化不显著, 耐干癐能力较强; 干痊胁迫对山桃根系性状影响显著, 山桃通过主动调节根系形态变化来适应不 断变化的环境, 具有较强的抗干痊能力; 栓皮柇的细根数量多, 吸收土壤水分、养分能力较强, 能够在干癐环境中快速生长。

关键词 : 观赏树种; 干癐立地; 根系功能性状; 适应对策

\section{Interspecific trait variation in the adaptation of root functional traits to dry- barren sites: A case study of the main ornamental tree species in stony mountainous region of Beijing}

WEI Liuduan $^{1,2}$, ZHU Jiyou ${ }^{1,2}$, LI Xirong ${ }^{1,2}$, SUN Guangpeng ${ }^{1,2}$, ZHANG Xinna ${ }^{1,2}$, XU Chengyang ${ }^{1,2, *}$

1 Research Center for Urban Forestry of Beijing Forestry University, Beijing 100083, China

2 Key Laboratory for Silviculture and Forest Ecosystem of State Forestry and Grassland Administration, Beijing 100083, China

\begin{abstract}
The changes and differences of root functional traits of different tree species in dry-barren site were analyzed, and the adaptive strategies of different tree species to dry-barren environment were studied. The experimental materials were mainly ornamental tree species (C.coggygria, Amygdalus davidiana and Quercus variabilis) in the shallow mountain area with same age and stand density. Fine roots of trees were obtained by digging, and morphological parameters of fine roots were measured. According to the field water holding capacity and gravel content of the sample plots, four dry and barren
\end{abstract}

基金项目:中央高校基本科研业务费专项资金(BLX201704); 朝阳区平原生态林定向抚育关键技术集成与规范 (CYSF- 1904); 国家自然科学基 金(31901277)

收稿日期:2020-01-02; 网络出版日期:2021-07-26

* 通讯作者 Corresponding author.E-mail: cyxu@ bjfu.edu.cn 
gradients (light, moderate, heavy and extreme) were set. The root functional traits of three ornamental tree species were analyzed and compared, and then the difference of root morphology of different tree species in dry-barren site and their adaptability to special habitats were studied. The results showed that drought and barrenness had an impact on the root functional traits of trees, but the degree of influence on different traits and different tree species was different, and the impact on Amygdalus davidiana was the largest; The root functional traits of the three tree species varied significantly under different dry-barren grades, and the change of the same traits varied with tree species. From mild drought to extreme drought, the root link length ( RL) of the three tree species decreased gradually, but the change of C.coggygria was not significant; The root tissue density (RTD) of C.coggygria and Quercus Variabilis variabilis decreased with the increase of dry and barren, but the Amygdalus davidiana increased with the increase of dry and barren; The specific root length (SRL) of C.coggygria and Amygdalus davidiana decreased from mild to extreme, and the SRL of Quercus variabilis increased with the increase of drought and barrenness; The specific root area (SRA) of C.coggygria increased with the increase of dry and barren soil, while the SRA of Amygdalus davidiana and Quercus variabilis decreased with the increase of dry and barren. Trees had a certain ability to respond and adapt to changes in dry-barren environments, which could adapt to the changing environment through their own morphological changes. Different species had different ways to adapt to the dry-barren environment, corresponding ecological adaptation strategies were adopted by balancing carbon allocation and carbon consumption. There were obvious differences between different tree species. Of the three tree species in this study, the root functional traits of C.coggygria did not change significantly in dry-barren environment, and the ability to tolerate dry and barren was strong; Dry and barren stress had a significant impact on the root traits of Amygdalus davidiana. By actively adjusting the morphological changes of the root system to adapt the changing environment, Amygdalus davidiana had a strong ability to resist dryness and barren; The fine roots of Quercus variabilis were abundant, so it could absorb soil moisture and nutrients, and could grow quickly in dry-barren environment.

Key Words : ornamental tree species; dry and barren sites; root functional traits; adaptation strategies

干旱、㾑薄是困难立地的重要特征, 也是限制林木生长的主导因子。北京浅山区以低山丘陵地貌为主,森 林植被以人工林为主。近些年来, 由于气候变化等原因, 北京市山地森林树木频发生长衰退、甚至个体死亡现 象。北京周边地区绿地建设和观赏树种培育对北京市的生态环境改善和美化有着积极的作用,但由于该区域 降水量少、土层浅、土壤保水较差、水土流失严重, 造成了干瘦的立地环境, 对林木的生长极为不利。养分和水 分常常同时限制干㾉环境下植物的生长 ${ }^{[1]}$, 根系是树木生长最基本、最重要的结构, 树木根系形态可反映树 木对生境的适应策略和土壤的固定、保持作用 ${ }^{[2]}$ 。因此, 通过测量干瘦环境中树木根功能性状 (Root functional traits, RFT), 进一步研究树木根系对干㾑立地的响应以及树木对干痊立地土壤资源获得对策, 一直 是近年来研究的热点。

根的形态特征和空间分布是影响水分、养分吸收的重要因素 ${ }^{[3]}$, 根直接与土壤接触, 更易对土壤环境做 出反应 ${ }^{[4]}$ 。在植物生长阶段环境因子对根系功能性状产生重要影响, 处于不同环境资源的植物根系外部形 态和内部生理机能会发生变化, 导致根系同一性状的特征有所差异, 从而表现出不同的生长方式和适应策 略 ${ }^{[5-6]}$ 。根系的大小、形态结构以及分布范围等直接决定着植物对土壤资源的吸收和利用能力 ${ }^{[7-8]}$, 同时决定 了植物对不利环境的适应, 成为植物生长的关键控制因素之一。它会随着环境胁迫的改变而进行调整, 以此 获取最大的资源量 ${ }^{[9]}$ 。根系构型是植物根系对环境响应和适应的具体表现, 干㾑环境中生长的植物通常在 幼苗期根系就开始快速地向下延伸, 以获取土壤深层的水分, 这对于植物的生长极为重要 ${ }^{[10-12]}$ 。

目前关于根系构型的研究主要位于西北干旱地区 ${ }^{[13-15]}$, 以干旱胁迫中植物根系的形态变化为主, 对养分 胁迫下植物根系的适应对策甚少, 而且大多数都以田间模拟试验为主, 难以还原真实环境下植物根系形态特 征的反应,在真实环境下不同树种根系性状对不同干㾑的反应方面报道极少。本研究主要探讨: (1) 在不同 干瘦环境中树木根系生长特性、抗 (而) 干痊程度在不同树种间是否存在显著差异; (2) 不同树种对干㾑的响 应方式和强度是否一致。本文以北京石质山地常见的 3 种观赏树种 (黄栌 (C.coggygria) 、山桃 (Amygdalus 
davidiana)、栓皮栋 ( Quercus variabilis) ) 为研究对象, 分析其根系连接长度、分支强度、组织密度、比根长、比根 表面积、根系密度, 从根系形态的变化揭示不同树种对干瘦的适应对策, 为干㾑立地植被恢复适树适地提供理 论依据和研究思路。

\section{1 材料与方法}

\section{1 试验材料}

试验区设置在西山国家森林公园 $\left(39^{\circ} 58^{\prime} \mathrm{N}, 116^{\circ} 11^{\prime} \mathrm{E}\right)$, 位于北京西郊小西山, 为石质山区, 属低山区。黄 栌 (C.coggygria) 是漆树科黄栌属, 是中国重要的观赏红叶树种, 耐干㾑和碱性土壤, 根系发达, 萌萺性强; 山桃 (Amygdalus davidiana) 属李亚科桃属, 而干癐, 对土壤适应性强; 栓皮栋 ( Quercus variabilis) 是壳斗科係属, 抗 旱、耐痊薄, 适应性强, 在酸性、中性及钙质土壤均能生长, 具有深根性。本文以林龄 (中龄林) 和林分密度相 对一致的黄栌、栓皮栋、山桃人工林作为研究对象, 林分内近期没有进行过抚育采伐, 避免根系生长受到人为 干扰。

\section{2 样品采集及处理}

\subsection{1 采样方法}

于 2019 年 7-8 月份进行野外取样。在林分内设置一个 $20 \mathrm{~m} \times 20 \mathrm{~m}$ 的临时样地, 共获得 128 个样地数 据, 其中黄栌有 57 个、山桃 36 个、栓皮栋 35 个。每个样地内按照 “S”字型选取 5 株平均木, 从树冠外缘往里 范围 $30 \mathrm{~cm} \times 50 \mathrm{~cm}$ 内取细根, 并在两林木之间挖一个 $30 \mathrm{~cm} \times 30 \mathrm{~cm}$ 的土坑, 将土坑内的根系全取; 在调查样地 沿对角线等距三点取 0- $10 \mathrm{~cm}$ 土层环刀土样, 并沿土壤垂直剖面取 0- $30 \mathrm{~cm}$ 混合土样, 各取 3 份。将根系样 品置自封袋、土壤样品置信封中, 带回实验室处理。

\subsection{2 干痊程度划分}

在实验室采用环刀控水法测量田间持水量, 称重法测量石砾含量, 根据调查样地田间持水量和石砾含量 的大小对干痊程度划分,如表 1 所示：

表 1 调查样地干旱程度和瘦薄程度划分

Table 1 Criteria for the classification of drought and barrenness in survey plots

\begin{tabular}{|c|c|c|c|}
\hline \multicolumn{2}{|c|}{ 干旱梯度 Drought gradient } & \multicolumn{2}{|c|}{ 㾑薄梯度 Barren gradient } \\
\hline 田间持水量/\% & 等级描述 & 石砾含量/\% & 等级描述 \\
\hline Field water holding capacity & Rank description & Gravel content & Rank description \\
\hline $0-20$ & 极度干旱 & $0-20$ & 轻度痒薄 \\
\hline $20-30$ & 重度干旱 & $20-40$ & 中度㾑薄 \\
\hline $30-40$ & 中度干旱 & $40-50$ & 重度㾑薄 \\
\hline$>40$ & 轻度干旱 & $>50$ & 极度㾑薄 \\
\hline
\end{tabular}

\subsection{3 林木根系性状的测定与计算}

根系清洗干净后, 用根系扫描仪 Epson Perfection V800 对根系扫描, 扫描时将根系放人透明托盘, 摆放时 尽量避免根系互相重叠和缠绕。利用图像分析软件 Winrhizo Pro 2004a 测定细根表面积 $\left(\mathrm{cm}^{2}\right)$ 、体积 $\left(\mathrm{cm}^{3}\right)$ 、 根长 $(\mathrm{cm})$ 等 $^{[16]}$, 根系连接长度 (Root link length, RL) 利用游标卡尺测量, 然后将样本装于牛皮纸信封内置于 烘箱内 $70{ }^{\circ} \mathrm{C}$ 烘干至恒重, 获得细根干重。相关性状的计算方法如下:

分支强度 (Branching intensity, BI) : 分叉数/根系长度

根组织密度 (Root tissue density, RTD: 根体积/干重

比根长 (Specific root length, SRL) : 根长/干重

比根表面积 (Specific root area, SRA): 根系表面积/干重

根表面积密度 (Root area density, RAD) : 根表面积 $/$ 土壤体积

根长密度 (Root length density, RLD) : 根长/土壤体积 


\section{3 数据处理}

利用 Microsoft Office Excel 2013 统计数据并绘制图表。利用 SPSS 分析软件对不同干旱、癐薄土壤条件中 根系形态指标进行差异性检验 (显著性水平 $\alpha=0.05$ ), 双因素方差分析 ( Two-way ANOVA) 研究干旱、痊薄以 及二者的交互作用对树木根系功能性状的影响, 结合 LSD、Duncan 对根系性状进行多重比较 $(P \leqslant 0.05)$ 。

\section{2 结果与分析}

2.1 土壤干旱、㾑薄及其交互作用对树木根系功能性状的影响

由表 2 可知,干旱、痊薄及其交互作用对 3 种树种的根系功能性状均影响显著,尤其是对山桃、栓皮柇的 根系功能性状具有极显著影响。干旱对黄栌 RL、RAD 具有显著影响, 对 SRL、RLD 具有极显著影响。癐薄对 其 SRL、SRA 影响显著, 对 RAD、RLD 具有极显著影响, 二者的交互作用对黄栌 RAD、RLD 具有极显著影响。 干旱、痊薄及其交互作用对山桃 BI、SRL、SRA、RTD、RAD、RLD 均具有极显著影响, 干旱、痊薄的交互作用对 山桃 RL 影响不显著, 但干旱、瘦薄两因素对山桃 RL 影响均极显著。干旱对栓皮栋 RL、BI、SRA、RTD、RAD、 RLD 影响极显著, 癐薄对其 RL、SRL、SRA、RAD、RLD 影响极显著,二者的交互作用对 SRL、SRA 显著影响, 对 $\mathrm{RLD} 、 \mathrm{RL} 、 \mathrm{BI}$ 影响极显著。

根据表 2 中 $F$ 值, 干旱、㾉薄及其二者的交互作用对 3 种树木根功能性状的影响程度各不相同, 干旱、痟 薄对大部分根系性状的作用均强于二者的交互作用。从黄栌的分析结果可知, 干旱、㾑薄以及二者的交互作 用对黄栌根功能性状的影响程度相差不大, 但干旱、癐薄对黄栌 SRL 的影响远大于二者的交互作用。对于山 桃,干旱和痊薄对 RL、BI、SRL、SRA、RAD、RLD 的影响远大于二者的交互作用,其中干旱对 RL、SRL 的影响程 度大于㾳薄的作用, 痊薄对 SRA 和 RLD 的影响程度大于干旱, 干旱、癐薄及二者的交互作用对山桃 RTD 的影 响程度相差不大。瘦薄对栓皮栋 RL、SRL、SRA、RAD、RLD 的影响大于干旱和交互作用, 干旱对 RTD 的影响 大于癐薄和交互作用, 二者的交互作用对 $\mathrm{BI}$ 的影响大于干旱、并远大于㾑薄作用, 干旱和㾑薄对栓皮栋 RL、 SRA、RAD 的影响远大于两者的交互作用。

2.2 树木根系功能性状在不同干瘦环境中的变化

\subsection{1 连接长度}

不同根功能性状和不同树种随土壤干旱、痊薄的加剧,表现出不同的变化,相同性状在不同树种中具有显 著差异 (图 1、图 2)。从轻度干旱到极度干旱, 3 种树种的 RL 均逐渐减小, 黄栌减少不显著; 山桃 RL 显著增 大后又显著减小, 中度干旱比轻度干旱增加 7.2\% $(P<0.01)$, 而重度干旱、极度干旱分别比中度干旱减小 26.9\% ( $P<0.01) 、 41.7 \%(P<0.01)$; 栓皮栋 RL 随干旱增强显著减少后极显著增大, 在极度干旱极显著减小达 到最小值。在土壤逐渐痊薄的条件下黄栌 RL 在中度痊薄减小后几乎保持不变,变化不显著; 山桃和栓皮栎 RL 均在极度癐薄时显著减小。

\subsection{2 分支强度}

$\mathrm{BI}$ 与 RL 的变化呈现出相反的趋势, 随着干旱的严重加剧, BI 变大, 在不同的㾑薄条件下, 变化不明显。 黄栌的 BI 在不同干旱、痊薄环境中变化不显著, 其变化规律一致, 从轻度到中度 BI 增强, 随后减弱后又增强, 在中度干旱达到最大值; 山桃随着干旱的加剧, 其 BI 显著增大, 当在极度干旱减少, 在重度干旱时 BI 最大。 山桃 BI 在㾑薄环境中变化不一致, 但中度、极度㾑薄 BI 均比轻度㾑薄大, 分别增加 $17.9 \%(P<0.01) 、 7.4 \%$ $(P<0.05)$; 栓皮栋 BI 随着干旱、㾉薄的加剧整体变化趋势均为随之增强, 在极度干旱和㾑薄中达到最大值, 分别比轻度增加了 $42.9 \%(P<0.01) 、 25.6 \%(P<0.01)$ 。

\subsection{3 比根长}

SRL 在轻度、极度干旱出现最大值或最小值, 在土壤中度或重度干旱条件下 SRL 显著增大, 随㾑薄的加 剧, 总的变化趋势是随之减小, 但也会呈现出相反的变化趋势。黄栌和山桃 SRL 在随着干旱、瘦薄的加剧, 表 现出一致的规律, 即从轻度到极度, 其SRL随即减小, 但是在不同瘦薄情况下的变化规律较明显。在不同干 


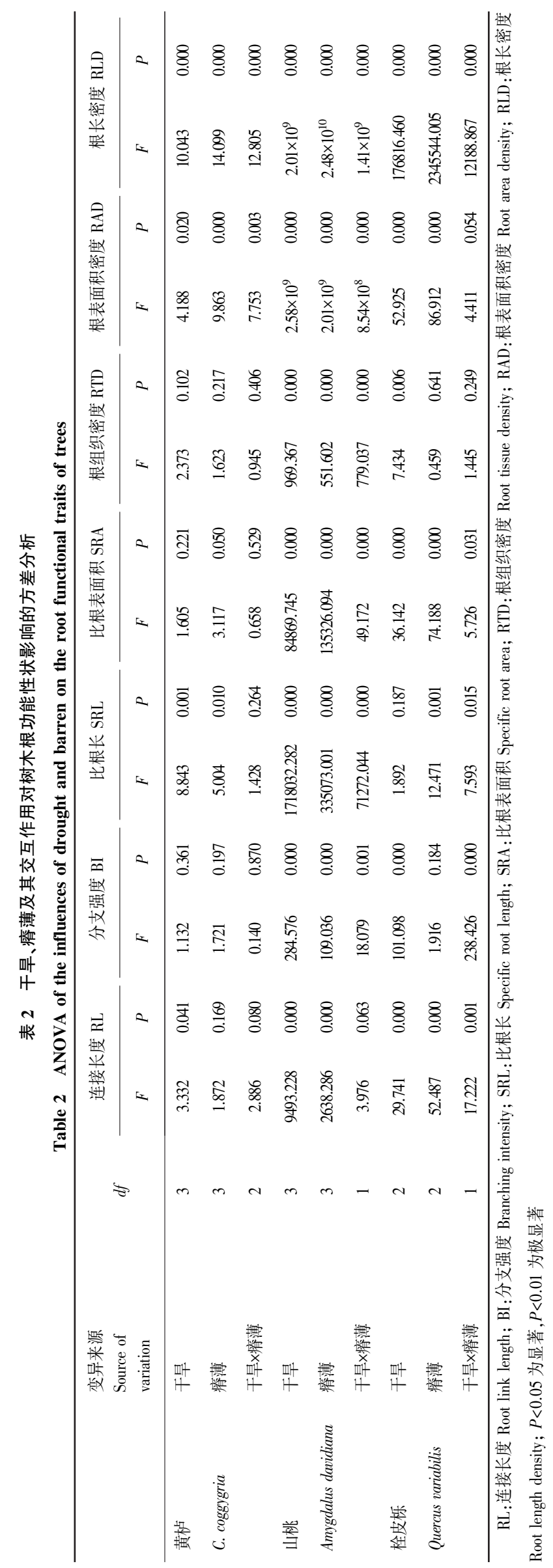

http ://www.ecologica.cn 
旱下黄栌和山桃 SRL 的最大值分别出现在轻度、中度干旱。相反, 栓皮栋 SRL 随着干旱、痊薄的加剧而随之 增大。栓皮栋在重度、极度干旱 SRL 分别比轻度干旱增加 17.6\% $(P>0.05) 、 28.8 \%(P<0.05)$, 重度干旱减少 $5.5 \%(P>0.05)$; 栓皮栋在中度、重度、极度㾑薄 SRL 分别比轻度㾑薄增加 $54.3 \%(P<0.01) 、 10.8 \%(P>$ $0.05) 、 45.5 \%(P<0.01)$, 其中在中度㾑薄栓皮栎 SRL 最大。

\subsection{4 根组织密度}

黄栌、栓皮栋 RTD 都随着干㾑的加剧而减小, 而山桃随着干㾑的加剧而增加。黄栌在不同干痊中 RTD 的变化都不显著, 但分别在重度干旱、极度痊薄有所下降; 山桃在中度、重度、极度干旱比轻度分别减少 $34.5 \%$ $(P<0.01) 、 25.9 \%(P<0.01) 、 28.7 \%(P<0.01)$, 中度痒薄比轻度㾑薄减少 $22.5 \%(P<0.01)$, 重度、极度疹薄比 重度分别增加 $20.9 \%(P<0.01) 、 44.1 \%(P<0.01)$; 栓皮栋 RTD 在中度干痊环境下呈现微小的减小后增加, 但 是在极度痊薄下降, 在极度干旱和重度癐薄 RTD 最大。

\subsection{5 比根表面积}

黄栌随干㾑的加剧,SRA 显著减小,而山桃、栓皮栋 SRA 随着干痊的加剧呈现出相反的变化。黄栌 SRA 在中度干旱比轻度减少 $19.7 \%(P<0.05)$, 随后增加 $14.1 \%(P>0.05)$, 在极度干旱下 SRA 减少到与中度干旱 一致。黄栌 SRA 随㾑薄的加剧而逐渐减少, 中度、重度、极度癐薄分别比轻度减少 $15.8 \%(P>0.05) 、 21.1 \%$ $(P<0.05)$ 和 $28.3 \%(P<0.01)$; 山桃 SRA 从轻度干旱到极度干旱呈现出极显著增加的变化, 在中度㾑薄环境 中山桃 SRA 极显著减小, 随后在重度、极度癐薄均呈现出极显著增大的变化; 栓皮栋 SRA 在中度干痊极显著 增大, 重度干痊下极显著减小, 几乎与轻度的数值相同,在极度干痊极显著增大。

\subsection{6 根系密度}

黄栌在不同干㾑环境中 RAD 和 RLD 变化都不显著, 在随着痊薄的加剧有增大的趋势, 均在重度痊薄中 达到最大值, 在极度癐薄呈现出不显著的减小; 随着干旱的加剧, 山桃 RAD、RLD 分别呈现出极显著减小、极 显著增加的变化, 在中度干旱 $\mathrm{RAD}$ 出现最小值, 但在极度干旱 RLD 极显著减小; 栓皮柇在随着干旱的加强, RLD 极显著减小, 中度、重度、极度干旱分别比轻度减少 $38.4 \%(P<0.01) 、 68.5 \%(P<0.01) 、 72.9 \%(P<$ $0.01)$ 。RAD 在中度干旱极显著下降, 重度干旱极显著增大而极度干旱极显著减小; 栓皮栋 RAD、RLD 均在中 度癐薄中出现最大值, 并且从中度㾑薄开始呈现极显著减小的变化。

\section{3 讨论}

土壤水分和养分是影响植物生长发育的重要非生物因素之一 ${ }^{[17]}$, 根系是最先感知土壤水分、养分变化的 器官, 是连接土壤与植物地上部分之间物质能量交换的重要桥梁, 其形态结构决定了植物对土壤资源的获取 能力 ${ }^{[18]}$ 。根系的变化是对环境的适应, 目的是为了有效吸收土壤中的水分和养分 ${ }^{[19]}$, 提高在不利环境中的 生存能力,但植物根系性状对干癐胁迫的适应因树种不同而异。

干旱、癐薄胁迫下的根系生长并不是单一的被促进或者被抑制, 而是与胁迫程度、树种有关 ${ }^{[18,20]}$ 。连接 长度是表征根系在地下空间的分布范围, 同时也反映了根系在土壤中的拓展能力 ${ }^{[21-24]}$; 根系分支强度是对土 壤资源的就地利用能力的指标, 可以表示根系分叉数的密集程度 ${ }^{[25]}$ 。随着土壤环境水分降低, 黄栌、山桃和 栓皮柇的根连接长度变小, 分支强度变大, 说明在干旱胁迫下 3 种树种通过增加侧根数量, 形成较多的分叉 数 ${ }^{[26]}$, 减少植株间资源传输距离, 保证个体间的资源连接和共享 ${ }^{[27]}$, 提高土壤水分资源就地利用率。但是山 桃、栓皮栋分别在中度、重度干旱其根连接长度显著增大, 在极度干旱分支强度减小, 增大连接长度减小分支 强度扩大根系在土壤的分布范围, 可以扩大根系的营养空间 ${ }^{[28]}$, 随着土壤干旱的加剧根连接长度又显著减 小、分支强度显著增大, 严重干旱时, 植物并没有增加根系深度来获取水分, 而是采取小根系来增强竞争 力 $^{[29]}$, 可以在根系扩展范围内对土壤水分原位利用。在痊薄胁迫中, 山桃、栓皮栎根系的根连接长度显著增 大, 而均在极度㾑薄显著减小, 分支强度也呈现逐渐增大的趋势, 但是在中度㾑薄中变化不明显, 而山桃在重 度癐薄根系分支强度极显著增大, 栓皮栋在极度痊薄极显著增大。根连接长度的增加避免了根系的交叠重 

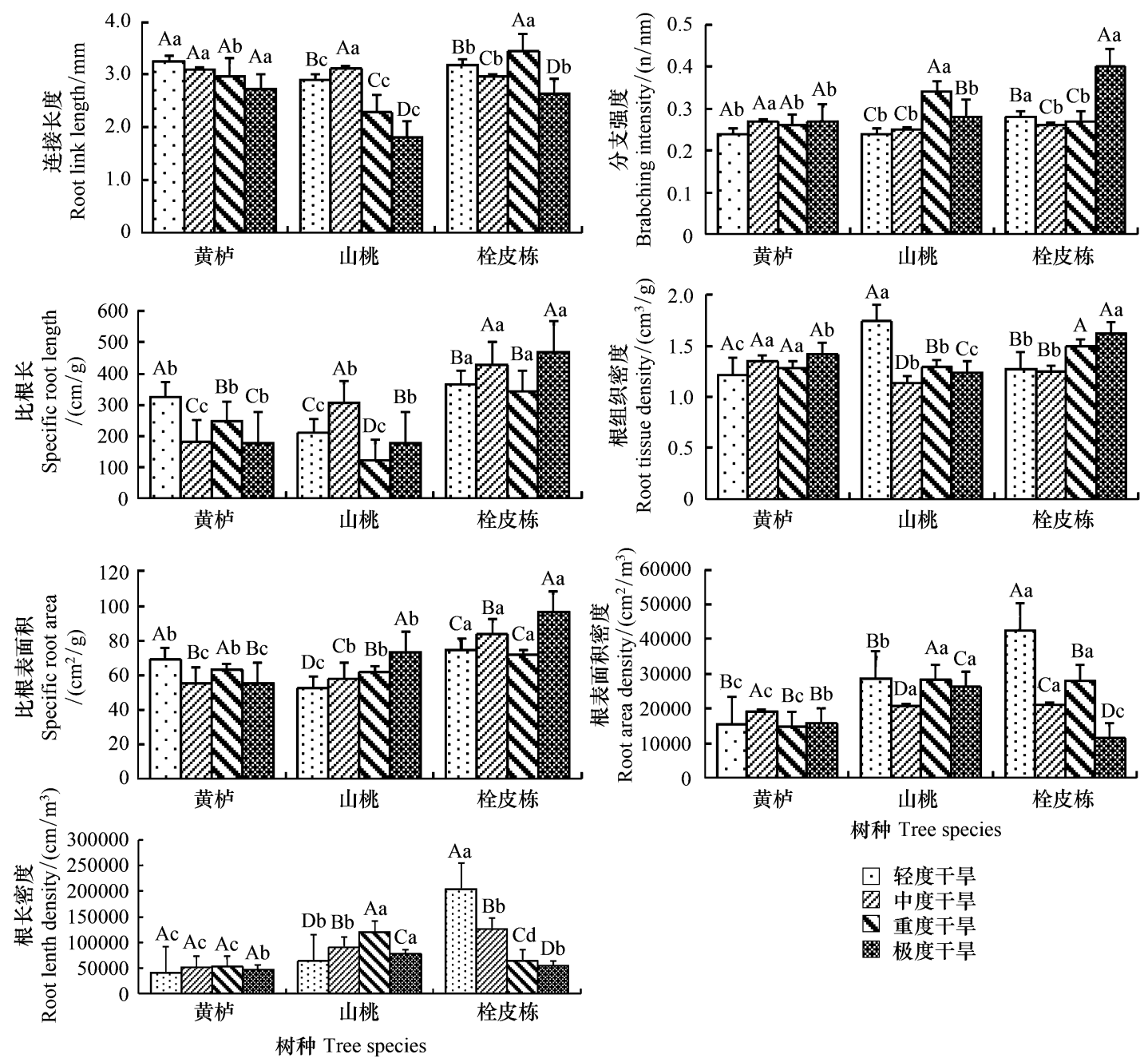

图 1 不同树种根系功能性状对干旱胁迫的响应

Fig.1 Response of root functional traits of different tree species to drought stress

大写字母表示同一树种不同干旱水平之间的差异显著性, 小写字母则表示不同树种间在同一干旱水平上的差异显著性

复, 分支强度增大增加了根系分叉数, 有助于根系在痊薄土壤中有效寻找更大范围养分的同时利用侧根对土 壤养分原位利用,增加根连接长度是根系对土壤贫㾑环境的一种适应策略 ${ }^{[21,30]}$ 。但随着土壤有效养分极度 㾑薄, 连接长度显著减小、分支强度显著增大, 山桃、栓皮柇逐渐发育出相对细密但向周围拓展能力较低的根 系结构, 这种分枝有利于提高植物对原位养分的利用效率 ${ }^{[26]}$ 。黄栌在轻度痊薄的根连接长度最大、分支强度 最小, 中度㾑薄下根连接长度减小、分支强度增大, 随着痊薄的加剧变化均不大, 但是黄栌的平均根连接长度 在 3 个树种中是最大的, 说明黄栌在㾑薄胁迫中根系在土壤中延伸范围较广, 但在轻度㾑薄的扩展范围最大, 而在痊薄加剧后扩展根系的同时增加了侧根分叉数,提高了对原位土壤养分的利用。

比根长是细根形态与生理功能的一个重要指标, 其高低与土壤资源有效性密切相关 ${ }^{[28]}$, 可以综合反映植 物吸收资源的能力与生态适应性 ${ }^{[31]}$; 比根表面积的值表示与土壤接触机会高低、可以反映植物根系的就地资 源利用能力; 根组织密度与抗逆相关, 代表物质咜存能力、对环境的耐受能力强与弱, 是细根生长和吸收能力 的重要指标 ${ }^{[25]}$ 。随着干痒程度增强, 黄栌比根长、比根表面积显著减小, 而根组织密度显著增大, 说明黄栌在 干癒、㾑薄胁迫下细根较少。干旱环境下, 根系生长在浅土区受到抑制, 且抑制作用随着降雨的减少而加 强 ${ }^{[32]}$, 而低养分环境有利于延长细根寿命 ${ }^{[33-36]}$, 干㾑使黄栌细根生产降低, 根系周转相对较慢, 减少了细根周 转对碳的消耗 ${ }^{[26,37]}$ 。但是黄栌在干旱、瘦薄胁迫下根组织密度增大, 根系物质贮存较好、吸收水分养分能力 

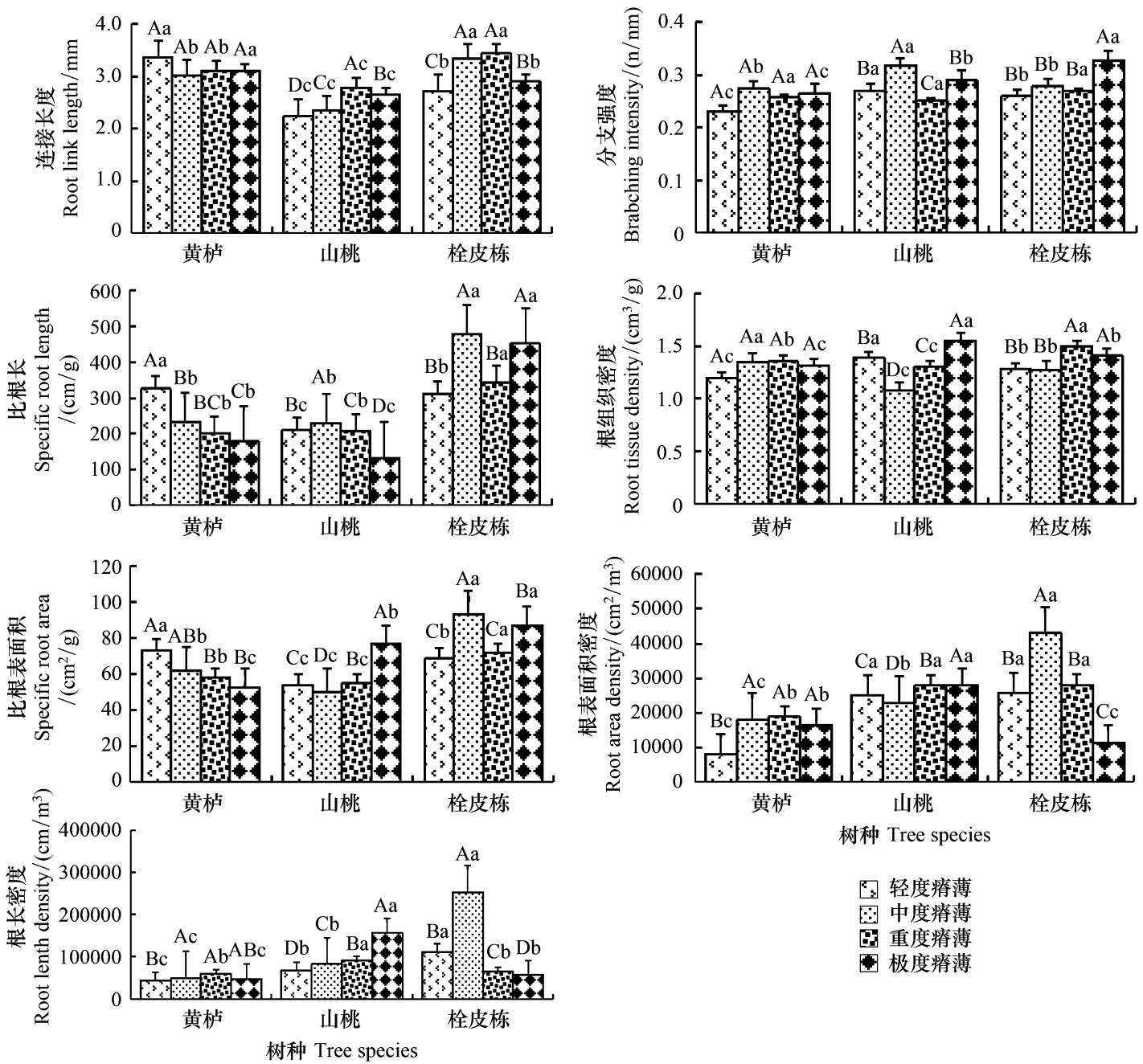

图 2 不同树种根系功能性状对痊薄胁迫的响应

Fig.2 Response of root functional traits of different tree species to barren stress

较强, 有效弥补了细根较少的不足。随着干㾑胁迫的加剧, 山桃比根长显著减小、比根表面积显著增大, 根组 织密度显著增大, 说明干旱胁迫抑制山桃的根系活性 ${ }^{[38]}$ 、限制根系生长 ${ }^{[39]}$, 在土壤水分和养分缺乏环境中根 系的根组织密度增大, 导致比根长减小 ${ }^{[10,40-41]}$ 。同时山桃具有较大的根面积有利于最大限度地吸收水分、养 分, 从而保存较多的稀缺营养, 导致根组织密度增大, 有利于山桃在严酷的生境中生存 ${ }^{[42]}$ 。因为根系吸收机 制是在比较肥沃的土层中尽可能投入较多的碳水化合物、尽可能多地吸收养分和水分 ${ }^{[43]}$, 所以山桃根组织密 度在轻度干旱、轻度痊薄时较大。栓皮栎比根长和比表面积随土壤干旱、痊薄胁迫增加而增加, 表明土壤水 分、养分胁迫诱导栓皮栎 产生更多数量、活力较强的新生细根, 从而使比表面积、比根长增加 ${ }^{[44]}$ 。这一现象 说明, 在土壤水分、养分胁迫下, 栓皮栎并不是被动忍受逆境胁迫, 而是主动调节其根系生长以提高对水分和 养分的吸收能力, 减缓逆境伤害。栓皮栋根组织密度也随着干瘠加剧而显著增加, 表明栓皮栋在干痒胁迫下 根系生长和吸收能力也越来越强, 有利于提高物质咜存能力、对环境的耐受能力。而且栓皮係的比根长、比根 表面积都比较大, 意味着栓皮栋对养分和水分等资源有着很强的竞争力, 这就使植物进行快速生长有了 可能 ${ }^{[42]}$ 。

根长密度表示单位体积土壤中根系总长度, 反映根系数量的多少 ${ }^{[45]}$, 对根系吸水和营养物质影响较 $大^{[46]}$ 。根表面积密度是单位土壤体积的总根表面积, 是研究水分吸收或养分吸收的重要参数之一 ${ }^{[47]}$ 。黄栌 根长密度、根表面积密度在不同干瘦环境中变化较小, 而且黄栌的根长密度、根表面积密度较小, 虽然在干瘦 
立地上黄栌细根不多,但是粗根或老根则可以更好地保持植物取得的土壤水分和养分 ${ }^{[48]}$, 以提高黄栌耐干㾑 能力。山桃根表面密度不同干痊环境中变化也较小,说明干痊、痊薄对山桃根表面积密度的影响不大,山桃利 用较大根表面积贮存营养物质, 而根长密度随干癐的加剧显著增大, 说明干旱胁迫都刺激了山桃根系的生长, 在干旱的环境条件下, 根系为了寻找更多水源, 增加根长密度 ${ }^{[47]}$, 但是在极度干旱时, 山桃根长密度显著减 小, 说明当土壤干旱超过一定的阈值后, 树木根系将逐步丧失其活力和功能 ${ }^{[38]}$ 。栓皮栋根长密度、根表面积 密度随干㾑加剧而减小, 但在中度痊薄中显著增大并达到最大值, 说明栓皮栋在中度㾑薄土壤环境中, 为获得 更多的土壤养分而采取主动适应的生态对策, 投人大量的光合产物至根系以刺激根系生长 ${ }^{[49]}$, 通过增加根系 与土壤的接触面积而获取更多的土壤养分资源。但是, 细根周转对干旱胁迫的响应较为敏感 ${ }^{[50]}$, 林木常因产 生的细根量大、根系周转速度较快而付出根系损失较大的代价 ${ }^{[51]}$, 所以为了减少细根周转对碳的消耗, 栓皮 係减小了对细根的生长。栓皮柇的根长密度、根表面积密度在干痊环境中的均值较大, 说明栓皮栋的细根数 量比黄栌、山桃多, 吸收土壤水分、养分能力强,在干痊环境中,栓皮柇是速生树种, 而黄栌、山桃是慢生树种。 总之, 植物对干㾑环境的变化都有一定的响应能力及适应对策, 且在漫长的进化过程中已经形成了一种自我 调节机制,能够通过自身根系形态变化来适应不断变化的环境,但不同树种对干㾑环境变化的适应策略不同, 具有明显差异 ${ }^{[52]}$ 。

\section{4 结论}

(1) 干旱、痈薄同时存在,且均对树木根功能性状产生影响。3 种树种根功能性状在不同干痊等级下发 生显著变化, 说明在干㾑环境下植物主动调节根系构型适应干痊立地。此外, 而且不同树种同一性状的变化 也各不相同,植物根系在适应极端干旱环境中, 通过改变根系形态和根系构型, 表现出显著的差异。

（2）在干㾑胁迫下,黄栌、山桃、栓皮栎均通过增加侧根分叉数、增大根组织密度和扩展根系在土壤中的 分布范围来提高抗干㾑能力。黄栌比根长、比根表面积在干痊中显著减小, 根系萌蓝性强; 山桃比根长显著减 小、比根表面积显著增大; 栓皮柇的比根长、比根表面积在干癐胁迫中比较大, 意味着栓皮柇对养分和水分等 资源有着很强的竞争力。

（3）植物对干痒环境的变化都有一定的响应能力及适应对策,且在漫长的进化过程中已经形成了一种自 我调节机制, 能够通过自身的形态变化来适应不断变化的环境。不同物种之间对干㾑环境变化的适应途径不 同,通过权衡碳分配、碳消耗采取了相应的生态适应策略, 不同树种间具有明显的差异。

\section{参考文献 (References) :}

[1 ] 李卫民, 周凌云. 水肥(氮)对小麦生理生态的影响 (I) 水肥(氮)条件对小麦光合蒸腾与水分利用的影响. 土壤通报, 2004, 35(2)： 136- 142 .

[ 2 ] 许维宏, 吴宁, 吴福忠. 干旱条件下植物生长适应策略研究进展. 世界科技研究与发展, 2010, 32(2): 176-179.

[ 3 ] Costa W D, Zörb C, Hartung W, Schubert S. Salt resistance is determined by osmotic adjustment and abscisic acid in newly developed maize hybrids in the first phase of salt stress. Physiologia Plantarum, 2007, 131(2): 311-321.

[ 4 ] 鄂玉江, 戴俊英, 顾慰连. 玉米根系的生长规律及其与产量关系的研究 I. 玉米根系生长和吸收能力与地上部分的关系. 作物学报, 1988, 14(2): 149-154.

[ 5 ] 伯姆. 根系研究法 $[M]$. 薛德榕, 谭协麟, 译. 北京: 科学出版社, 1985.

[ 6 ] Comas L, Bouma T, Eissenstat D. Linking root traits to potential growth rate in six temperate tree species. Oecologia, 2002, 132(1): 34-43.

[ 7 ] 王珺, 刘茂松, 盛晟, 徐驰, 刘小恺, 王汉杰. 干旱区植物群落土壤水盐及根系生物量的空间分布格局. 生态学报, 2008(9): 4120-4127.

[ 8 ] Cheng X R, Huang M B, Shao M G, Warrington D N. A comparison of fine root distribution and water consumption of mature Caragana korshinkii Kom grown in two soils in a semiarid region, China. Plant and Soil, 2009, 315(1/2): 149- 161.

[9] 赵文霞. 亚热带常绿阔叶林常见树种根茎叶功能性状研究 [D]. 北京: 北京林业大学, 2016.

[10] Markesteijn L, Poorter L. Seedling root morphology and biomass allocation of 62 tropical tree species in relation to drought-and shade-tolerance. Journal of Ecology, 2009, 97(2): 311-325.

[11] Cortina J, Green J J, Baddeley J A, Watson C A. Root morphology and water transport of Pistacia lentiscus seedlings under contrasting water supply: A test of the pipe stem theory. Environmental and Experimental Botany, 2007, 62(3): 343-350.

[12] Green J J, Baddeley J A, Cortina J, Watson C A. Root development in the Mediterranean shrub Pistacia lentiscus as affected by nursery treatments. Journal of Arid Environments, 2005, 61(1): 1-12. 
[13] 杨小林, 张希明, 李义玲, 李绍才, 孙海龙. 塔克拉玛干沙漠腹地 3 种植物根系构型及其生境适应策略. 植物生态学报, 2008, 32( 6) : 1268-1276

［14］杨小林, 张希明, 李义玲, 解婷婷, 王伟华. 塔克拉玛干沙漠腹地几种植物根系分形特征. 干旱区地理, 2009, 32(2): 249-254.

[15］郭京衡, 曾凡江, 李尝君, 张波. 塔克拉玛干沙漠南缘三种防护林植物根系构型及其生态适应策略. 植物生态学报, 2014, 38(1) : 36-44.

[16] 李金航, 徐程扬, 朱济友, 王秀松, 陈治羊, 赵凯. 黄栌幼苗在持续干旱胁迫环境中的表型适应对策. 西北林学院学报, 2019, 34(2)： 28-34.

［17］庞世龙,欧芷阳，申文辉, 郝海坤, 彭玉华. 干旱胁迫对蚬木幼苗表型可塑性的影响. 中南林业科技大学学报, 2017, 37(5): 21-25.

[18］李金航, 齐秀慧, 徐程扬, 王毅梅. 华北 4 产地黄栌幼苗根系形态对干旱胁迫的短期响应. 北京林业大学学报, 2014, 36(1) : 48-54.

[19］夏菲. 黄土高原子午岭辽东栋幼苗根系形态结构特征的研究 [D ]. 西安: 陕西师范大学, 2012.

[20] Sapeta H, Costa J M, Lourenco T, Maroco J, Linde P V D, Oliveira M M. Drought stress response in Jatropha curcas: growth and physiology. Environmental and Experimental Botany, 2013, 85(x): 76-84.

[21] 何广志, 陈亚宁, 陈亚鹏, 王日照. 柽柳根系构型对干旱的适应策略. 北京师范大学学报(自然科学版), 2016, 52 (3) : 277-282.

[22] Schenk H J, Jackson R B. Rooting depths, lateral root spreads and below-ground/above-ground allometries of plants in water-limited ecosystems. Journal of Ecology, 2002, 90(3): 480-494.

[23] Schenk H J, Jackson R B. The global biogeography of roots. Ecological Monographs, 2002, 72(3) : 311-328.

[24] Walk T C, Erik V E, Lynch J P. Modelling applicability of fractal analysis to efficiency of soil exploration by roots. Annals of Botany, 2004, 94 (1): 119-128

[25]邓否, 关晋宏, 张文辉. 辽东栋幼苗根系形态特征对环境梯度的响应. 生态学报, 2018, 38(16) : 5739-5749.

[26] 李金航, 周玫, 朱济友, 徐程扬. 黄栌幼苗根系构型对土壤养分胁迫环境的适应性研究. 北京林业大学学报, 2020, 42(3): 65-77.

[27] 宋清华, 赵成章, 史元春, 杜晶, 王继伟, 陈静. 不同坡向甘肃臭草根系分叉数和连接长度的权衡关系. 植物生态学报, 2015, 39(6)： 577-585.

［28］单立山, 李毅, 任伟, 苏世平, 董秋莲, 耿东梅. 河西走廊中部两种荒漠植物根系构型特征. 应用生态学报, 2013, 24(1)：25-31.

[29] 刘锦春, 钟章成, 何跃军. 干旱胁迫及复水对喀斯特地区柏木幼苗活性氧清除系统的影响. 应用生态学报, 2011, 22(11): 2836-2840.

[30］杜建会, 刘安隆, 董玉祥, 胡绵友, 梁杰, 李薇. 华南海岸典型沙生植物根系构型特征. 植物生态学报, 2014, 38(8): 888-895.

[31］徐琨, 李芳兰, 荷水燕, 包维楷. 峮江干旱河谷 25 种植物一年生植株根系功能性状及相互关系. 生态学报, 2012, 32(1): 215-225.

[32］梁千慧. 不同水分条件下黑麦草对喀斯特土壤深度的生长与生理响应 [D]. 重庆: 西南大学, 2016.

[33] Nadelhoffer K J, Aber J D, Melillo J M. Fine roots, net primary production, and soil nitrogen availability: a new hypothesis. Ecology, 1985 , 66 (4) : $1377-1390$

[34] Aber J D, Melillo J M, Nadelhoffer K J, Pastor M C , Pastor M C. Fine root turnover in forest ecosystems in relation to quantity and form of nitrogen availability: a comparison of two methods. Oecologia, 1985, 66(3): 317-321.

[35] Majdi H, Nylund J E. Does liquid fertilization affect fine root dynamics and lifespan of mycorrhizal short roots?. Plant and Soil, 1996, 185(2) : 305-309.

[36] Pregitzer K S, Zak D R, Curtis P S, Kubiske M E, Teeri J A, Vogel C S. Atmospheric $\mathrm{CO}_{2}$, Soil nitrogen and turnover of fine roots. New phytologist, 1995, 129(4): 579-585.

[37] 梅莉, 王政权, 程云环, 郭大立. 林木细根寿命及其影响因子研究进展. 植物生态学报, 2004, 28(5) : 704-710.

[38］赵忠, 李鹏. 渭北黄土高原主要造林树种根系分布特征及抗旱性研究. 水土保持学报, 2002, 16(1): 96-99, 107-107.

[39］ 孔艳菊, 孙明高, 胡学俭, 苗海霞. 干旱胁迫对黄栌幼苗几个生理指标的影响. 中南林学院学报, 2006, 26(4) : 42-46.

[40] Wahl S, Ryser P. Root tissue structure is linked to ecological strategies of grasses. New Phytologist, 2000, 148(3) : 459-471.

[41] Cornelissen J H C, Lavorel S, Garnier E, Díaz S, Buchmann N, Gurvich D E, Reich P B, Steege H T, Morgan H D, Heijden M G A V D, Pausas J G, Poorter H. A handbook of protocols for standardised and easy measurement of plant functional traits worldwide. Australian Journal of Botany, 2003, 51(4) : 335-380.

[42] 蒋礼学, 李彦.三种荒漠灌木根系的构形特征与叶性因子对干旱生境的适应性比较. 中国沙漠, 2008, 28(6): 1118-1124.

[43] Fransen B, Berendse K F. Root morphological plasticity and nutrient acquisition of perennial grass species from habitats of different nutrient availability. Oecologia, 1998, 115(3): 351-358.

[44] 单立山, 李毅, 段雅楠, 耿东梅, 李真银, 张荣, 段桂芳, Жигунов, Анатолий Васильеви. 红砂幼苗根系形态特征和水分利用效率对土 壤水分变化的响应. 西北植物学报, 2014, 34(6): 1198- 1205.

[45] 邹海洋, 张富仓, 吴立峰, 向友珍, 范军亮, 李志军, 李思恩. 基于不同水肥组合的春玉米相对根长密度分布模型. 农业工程学报, 2018, $34(4): 133-142$.

[46] Pregitzer K S, Deforest J L, Burton A J, Allen M F, Ruess R W, Hendrick R L. Fine root architecture of nine North American trees. Ecological Monographs, 2002, 72(2): 293-309.

[47］黄晶晶, 井家林, 曹德昌, 张楠, 李景文, 夏延国, 吕爽. 不同林龄胡杨克隆繁殖根系分布特征及其构型. 生态学报, 2013，33(14)： 4331-4342.

[48］赵富王, 王宁, 苏雪萌, 李秋嘉. 黄土丘陵区主要植物根系对土壤有机质和团聚体的影响. 水土保持学报, 2019, 33(5)：105-113.

[49] Du N, Wang R Q, Liu J, Zhang X R, Tan X F, Wang W, Chen H, Guo W H. Morphological response of Vitex negundo var. heterophylla and Ziziphus jujuba var. spinosa to the combined impact of drought and shade. Agroforestry Systems, 2013, 87(2) : 403-416.

[50］张小全. 环境因子对树木细根生物量、生产与周转的影响. 林业科学研究, 2001, 14(5): 566-573.

[51] Gill R A, Jackson R B. Global patterns of root turnover for terrestrial ecosystems. New Phytologist, 2000, 147 (1) : 13-31.

[52］郑淑霞, 上官周平. 近 70 年来黄土高原典型植物 $\delta^{13} \mathrm{C}$ 值变化研究. 植物生态学报, 2005, 29(2): 289-295. 